\title{
Status and Sacredness: A General Theory of Status Relations and an Analysis of Indian Culture. By Murray Milner, Jr. New York: Oxford University Press, 1994. xiii, 336 pp.
}

\author{
Reviewed by Karen Leonard, Professor of Anthropology, School of Social \\ Sciences, University of California, Irvine CA 92717-5100.
}

Murray Milner, Jr., has undertaken an ambitious project on many counts. His book is about social theory and also about the Indian caste system and Hinduism; it is about the false dichotomy between "interpretive" and "scientific" methodologies and also about the need to transform society. For the sake of the earth's ecology, Milner argues that status, by which he means social worth and value, must be less closely tied to economic and political power. He analyzes India because he feels "the culture of premodern India ... has been relatively successful over a long period of time in insulating status from economic and political power (p. 16)."

A serious and commendable attempt to understand Indian society and make it more accessible to non-specialists on India, Milner's analysis is successful on some levels. He has drawn upon many excellent scholarly works on Indian society and religion with skill and sensitivity, and his development of theoretical concepts to explain the Indian material is rigorous and logical. I expect that many readers will be well introduced to the complexities of India through this book. The complexities are such that he cannot explain it all, of course, and many of one's criticisms are anticipated and dealt with in caveats and discussions of the limits of the analysis. But the fundamental problem is one of historical emphasis.

Milner has been captivated by Brahmanical tradition, Hindu India, the Sanskritic "Great Tradition." From his exposition, one would hardly know that equally rich Mughal and British Indian traditions succeeded the early Hindu ones and indeed have dominated the subcontinent, in succession, for the last five hundred years. Both of these traditions are at present controversial. The Mughal and other Muslim rulers are being dramatically misinterpreted and their many positive contributions in danger of being erased from Indian history, and the British rulers are being condemned not only for economic and political subversions but for an Orientalist construction/strengthening of the very Brahmanical culture Milner sees as his object of study. Neither controversy finds discussion here. Instead, an unproblematic "traditional India (p. 120)" is presented to illustrate the applicability of Milner's theory of resource structuralism.

Confusion about historical change shows up most strongly in his concluding chapter 16, where he talks of limitations due to the lack of historical data but maintains that his study of "traditional India" presents characteristics present "in most time periods that we know about (p. 228)." Admitting that he pays little attention to contemporary urban India, he sees his contribution as a sound, albeit "ahistorical," analysis of the "traditional" social structure; then he defends himself against the "ahistorical" charge by saying that an explanation of a system's current (my emphasis) rules and operations is still valid. He also recognizes here that he deals "almost exclusively" with Hindu India (p. 229). 
Milner is convinced of the ideological centrality and historical continuity of Brahmanical notions of ritual purity and caste status, "the relative stability of Indian social structure at the village level," and "the Brahmans' prominent and often dominant position as cultural and religious leaders over a long period (p. 56)." Historical studies of castes in Mughal or British administrative settings and studies of popular religion where Brahmanical notions are unknown or do not fit have not been used. One can hardly fault him, however, for a poor command of the literature, and scholars whose work fits in with his views and development of theory have been used well. His discussion of sacredness and status in Hinduism, chapters 12-15, is generally very well done, based on excellent recent work, and brief contrasts with Christianity add a comparative dimension. In his writing, salvation or moksha is analyzed as the ultimate form of social mobility or status transformation, but the quoted poetry from various bhakti (devotional) movements should introduce many to some of the special delights of Hindu doctrine and practice. Even here, however, his notion of Brahman dominance sometimes leads him astray. He says that in Europe the priesthood was in principle always open to those of low status origins, "which certainly has never been the case in Hinduism (p. 217)," apparently forgetting that in recent centuries secular Brahmans have always ranked above priestly Brahmans, and that persons of any status or gender can become sanyasis (world renouncers) and sanyasis are often gurus or religious preceptors for lay Hindus.

I do not mean to underestimate Milner's achievement. The book is the product of much hard work and hard thinking, and his prose is clear and forceful (but the editor did not catch some instances of lack of agreement between subject and verb or modifier.) Milner has mastered an extensive and difficult body of material, understood it through social science theory, and used it to suggest further advances in that theory. It may be that this study will lead to real advances, particularly in the moving of the "unique" case of Indian society into the mainstream of sociological analysis.

\section{Women in Pain: Gender and Morbidity in Mexico. By Kaja Finkler. Philadelphia: University of Pennsylvania Press, 1994 xviii, 238 pp.}

\section{Linda M. Whiteford, Ph.D., MPH Professor and Director of Graduate Programs in Applied Anthropology, University of South Florida.}

This is an ambitious book. In her book, Women in Pain: Gender and Morbidity in Mexico, Finkler sets out to explain the differential morbidity patterns experienced by men and women in Mexico. The author has been conducting research and observing Mexican life for 20 years, during which time she has lived with families, trained as a Spiritual healer and studied biomedical practices in one of the largest hospitals in Mexico City. The author's knowledge of the population she addresses is evident on every page and in every description, as is her grasp of the complexity of issues surrounding the women whose pain she describes.

Finkler writes that her goal in writing this book is to "deepen our grasp of human sickness...and to do so I focus on what I call life's lesions.... Contemporary biomedicine has unquestionably made dazzling advances and has succeeded in treating complex medical impairments. At the same time, biomedicine often fails to alleviate patients' 